Click www.researchjournal.co.in/online/subdetail.html to purchase.

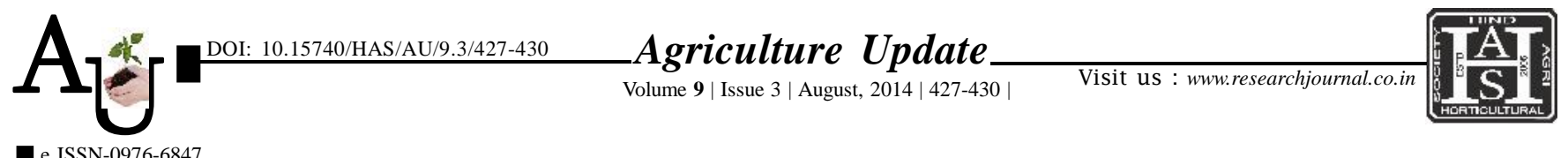

\title{
Evesearch Article Evaluation of growth and yield parameters of green gram (Vigna radiata L.)
}

\section{T.K. SAMANT}

Article Chronicle: Summary : A farmers' participatory field trial was conducted to evaluate the growth and yield parameters of Received : 14.06.2014;

Revised : 12.07.2014; Accepted :

21.07.2014

KEY WoRds: CGR, Economics, Greengram, HYV, LAI

Author for correspondence :

\section{T. K. SAMANT}

Krishi Vigyan Kendra, ANGUL (ODISHA) INDIA Email: tksamant_2003@ yahoo.co.in different high yielding varieties of green gram at Tainsi village of Angul block in Angul district of Odisha with the financial support from ATMA during Kharif season of 2012 and 2013. The treatments were consisted of five different high yielding green gram varieties viz., OBGG 52, OUM 11-5, IPM 02-14, Pant M-5, TARM 1 and one local variety Kala mung. Among different varieties, OBGG 52 recorded maximum seed yield $\left(13.6 \mathrm{q} \mathrm{ha}^{-1}\right)$, stover yield $\left(55.65 \mathrm{q} \mathrm{ha}^{-1}\right)$, length of pod $(7.9 \mathrm{~cm})$, number of pods plant ${ }^{-1}(30.6)$, number of seeds pod ${ }^{-1}(12.2)$, number of nodules plant ${ }^{-1}$ (3.85 to 13.2). The same variety also produced the maximum leaf area index(4.54), total dry weight (328.42 $\left.\mathrm{g} \mathrm{m}^{-2}\right)$, crop growth rate $\left(7.41 \mathrm{~g} \mathrm{~m}^{-2}\right.$ day $^{-1}$ ) with net return (Rs. $26050 \mathrm{ha}^{-1}$ ) and B:C ratio (2.21) and was found to be most suitable. HYV Pant M-5 produced maximum number of branches plant ${ }^{-1}(10.2)$ and 100 seed weight $(4.15 \mathrm{~g})$ where as the local variety Kala mung produced the lowest no of pods plant ${ }^{-1}(19)$, number of seeds pod $^{-1}(8.4)$, leaf area index (3.12), crop growth rate $\left(5.95 \mathrm{~g} \mathrm{~m}^{-2} \mathrm{day}^{-1}\right)$, seed yield $\left(7.8 \mathrm{q} \mathrm{ha}^{-1}\right)$ and net return (Rs.9450 ha-1). Hence, the existing local variety (Kala mung) can be replaced by HYV OBGG 52 since it fits to the existing farming situation for higher productivity and income.

How to cite this article : Samant, T.K. (2014). Evaluation of growth and yield parameters of green gram (Vigna radiata L.). Agric. Update, 9(3): 427-430. 